\title{
MENDENGARKAN SEBAGAI MODEL KOMUNIKASI UNTUK MEMAHAMI REMAJA
}

\author{
Fabianus Fensi \\ Program Studi Psikologi Universitas Bunda Mulia \\ fabianusfensi@gmail.com
}

\begin{abstract}
Adolescence is full conflict period in the life of teens are signed by rebellion behavior dynamic and avoid order and social norms. Freedom become the main demands and family with their norms produced are seens as cause of their not free situations. Parents should be understand these problems as something that has to be faced, no judge them as disorder. By the literature analysis this study recommends interpersonal communication model that is listening as the way to understand the teens problems adequately. Listening communication give the parents change to take apart in teens selfdevelopment empathicly.
\end{abstract}

Keywords: adolescence; parents; interpersonal communication; listening

\begin{abstract}
ABSTRAK
Masa remaja adalah masa penuh gejolak ditandai oleh dinamika perilaku memberontak dan melawan semua aturan dan norma sosial. Kebebasan menjadi tuntutan karena institusi keluarga beserta norma-norma yang dihasilkannya dipandang sebagai penyebab dari ketidakbebasan mereka. Orang tua seharusnya memahami perkembangan ini sebagai sesuatu yang harus diterima dan dihadapi, bukannya menghakim perilaku remaja sebagai tidak tahu aturan. Melalui analisis/kajian literatur studi ini merekomendasikan model komunikasi interpersonal yang mendengarkan sebagai jalan untuk memahami dengan penuh tanggung jawab permasalahan yang dihadapi, bahkan dilakukan remaja. Komunikasi yang mendengarkan memberi ruang yang cukup bagi orang tua untuk mengambil bagian secara empatik dalam masalah perkembangan jati diri remaja.
\end{abstract}

Kata Kunci: remaja; orang tua; komunikasi interpersonal; mendengarkan

\section{PENDAHULUAN}

\subsection{Latar Belakang}

Oleh banyak hasil studi, masa remaja dianggap sebagai fase paling unik dalam kehidupan seseorang. Unik karena kehadirannya ditandai oleh tiga fenomena sekaligus, yakni: penuh dinamika, konfrontatif, dan mencemaskan.

Sebagai sebuah dinamika, masa remaja disambut dengan penuh kekaguman. Di satu pihak seorang remaja mulai mengagumi dirinya sebagai "cantik, ganteng, baik, menarik, kuat, penuh perhatian, dan lain sebagainya, pun dilain pihak, dia mulai mengagumi orang lain persis sama dengan ketika dia mengagumi dirinya sendiri. Dia mulai berani memuji orang lain sebagai cantik, ganteng, menarik, baik, dan lain-lain persis sama seperti ketika dia memuji dirinya dengan penyebutan serupa. Selain disambut dengan penuh kekagumam, dinamika masa remaja ditandai pula oleh mulai terbangunnya rasa menghargai diri sendiri dan orang lain di sekitarnya. Menariknya, proses menghargai ini justeru dilakukan untuk merawat rasa kagum, tidak saja supaya tidak hilang, tetapi juga supaya menarik sebanyak mungkin orang untuk mengagumi dirinya.

Menampilkan diri lebih rapih, cara berpakaian yang menarik perhatian, menabur wangi-wangian pada tubuh dan pakaian yang dikenakan, cara bertutur kata yang lemah lembut, dan lain-lainnya, tidak saja dimaksudkan untuk merawat kecantikan dan kegantengan fisik, tetapi lebih dari itu seorang 
remaja sudah mulai tumbuh dalam dirinya rasa menghargai dirinya sendiri, dan pun menghargai orang lain di sekitarnya. Lebih dari sekadar memicu rasa tertarik orang lain kepada dirinya, memakai wangi-wangian, berpakaian sopan, rambut disisir rapih juga sebuah ekspresi bahwa seorang remaja sedang menghargai orang lain yang dihadapinya.

Namun, di sisi lain, proses dinamis penuh janji ini melahirkan antagonismenya sendiri. Kekagumannya kepada orang lain menuntut kebebasan. Kebebasan menuntut tersedianya ruang ekspresi atas rasa kagum. Keterbatasan ruang ekspresi, atau lebih lebih tepatnya, ruang kebebasan yang tidak sepenuhnya dibuka untuk mengekspresikan kekaguman pada orang lain, baik atas nama aturan, norma sosial, nilai, dan maupun pandangan orang lain pada umumnya, melahirkan pemberontakan yang konfrontatif.

Masa remaja dalam pandangan McCaffrey (1998) adalah masa di mana seorang anak muda memiliki kecenderungan: (1) Berusaha menjawabi berbagai pertanyaan mengenai otoritas dirinya; (2) Mencoba sekuat tenaga untuk mengalami kebebasan penuh; dan (3) Berkonflik dengan orang dewasa. Tiga lingkungan sosial yang menjadi sasaran dari kecenderungan ini adalah orang tua di rumah, guru di sekolah, atau mungkin atasan mereka di tempat kerja. Remaja berusaha dengan caranya, mau keluar dari zona nyaman aturan, norma, dan tata nilai yang ada. Atau, remaja mau keluar dari zona nyaman keluarga dan masyarakat karena merekalah yang menciptakan tata nilai menjadi serba seragam dalam kehidupan remaja.

Zona nyaman norma, aturan, dan tata nilai diproyeksikan sebagai sesuatu yang membelenggu, dan bahkan memenjarakan ekspresi diri lalu remaja mulai mengidealkan nilai baru, norma, aturan baru yang mereka ciptakan sendiri bersama peer group. Ekspresi diri ideal bagi mereka adalah mengambil bagian dalam proses membangun norma baru dan menikmati hasilnya bersama teman-temannya. Norma baru yang diciptakan biasanya berlawanan, menyalahi, dan bertentangan sama sekali dengan norma mainstream yang diciptakan keluarga (orang tua) dan masyarakat pada umumnya.

Dialektika antara kemapanan nilai, norma, dan aturan lama dengan berhasil disepakatinya nilai baru berdasarkan pleasure principle ini justeru mencemaskan, tidak saja bagi orang tua pencetus doktrin serba mapan bagi para remaja (karena dilahirkan jauh sebelum seorang remaja lahir), tetapi juga, sebenarnya mencemaskan bagi kaum remaja sendiri, karena mereka menciptakan norma baru di atas dasar yang belum sepenuhnya bisa diterima masyarakat pada umumnya. Lalu, apa yang harus dilakukan? Perlu pemahaman yang utuh dari orang tua untuk bisa menerima kenyataan ini.

Joseph A. Califano, pendiri sekaligus Presiden Nasional Pusat Penyalahgunaan Zat Adiktif pada Universitas Columbia (2008), mengakui bahwa para orang tua sebenarnya sudah melakukan banyak hal yang terbaik untuk remaja. Lewat surveinya terhadap para remaja yang suka merokok, minum minuman keras, penggunaan obat-obatan terlarang, dia menemukan adanya indikasi lemahnya kontrol lewat komunikasi menyebabkan orang tua: gagal mengawasi perilaku anak; gagal melindungi anak dari pemakaian zat-zat adiktif; gagal mengidentifikasikan persoalan penyebab sehingga anak terjerumus dalam masalah obat-obatan terlarang; dan yang paling penting adalah orang tua gagal untuk menjadikan dirinya panutan untuk anak-anak mereka.

Fenomena yang sering terjadi bahwa masalah komunikasi selalu menunjuk pada tidak terjadinya aliran komunikasi yang positif antara orang tua dengan anak remaja. Kondisi tersebut muncul dalam perilaku orang tua, seperti: cenderung menyalahkan, membangun sikap tidak mempercayai anak, melakukan kritik tanpa memberi jalan pemecahan, lemahnya afeksi untuk memahami, tidak memberi dukungan yang kuat atas apa yang dicapai remaja, dan lemahnya penerimaan orang tua atas masalah yang sedang dihadapi remaja (Disiye, Margaret A, Hezborn M.N. Kodero, 2015).

Untuk mengatasinya dibutuhkan komunikasi terbuka dengan komponen penting berikut, antara lain: kebiasaan mendengarkan yang baik; memberi ruang bagi kebebasan remaja untuk berekspresi, dukungan, kepercayaan, dan penyelesaian masalah (Ibid., Disiye, Margaret A, Hezborn).

Seperti membenarkan dua kajian ini, Liuhua Ying, dkk (2015) dari Departemen 
Psikologi, Universitas Zhejiang Sci-Tech, Hangzhou dari hasil penelitiannya mengenai pengawasan dan komunikasi orang tua dengan anak remaja di Cina, mengatakan bahwa hubungan saling kepercayaan antara orang tua dan remaja hanya bisa dibangun lewat komunikasi.

Bertolak dari latar belakang yang digambarkan, kajian ini mencoba mendeskripsikan persoalan riil yang banyak dihadapi kaum remaja; lalu tindakan-tindakan apa yang seharusnya bisa dilakukan orang tua; dan menawarkan satu model komunikasi interpersonal yang mendengarkan ketika orang tua menghadapi remaja dengan segala problematikanya.

\subsection{Tujuan Penelitian}

Kajian ini dimaksudkan untuk mencari jalan tengah, Pertama, memperkuat basis penjelasan rasional atas nilai-nilai doktrinal yang dibangun keluarga/masyarakat untuk kebaikan remaja; Kedua, mengadaptasi perkembangan baru dalam tata nilai yang dianut remaja dan berusaha menggesernya dari pengagungan pleasure principle kepada penguatan utilities principles. Ketiga, mempertimbangkan komunikasi sebagai jalan damai antara stabilitas normatif nilai yang dipilih oleh masyarakat dengan janji ideologis dari nilai baru yang disepakati untuk dianut kaum remaja pada masanya. Model komunikasi yang dianjurkan adalah mendengarkan.

\section{TINJAUAN PUSTAKA}

Kita selalu sepakat dengan kriteria seseorang disebut remaja kalau usianya memiliki rentang waktu $12-21$ tahun untuk wanita dan $13-22$ tahun untuk laki-laki. Atau, mengikuti versi Perserikatan BangsaBangsa (PBB) seseorang disebut remaja kalau berumur 15-24 tahun. Mendekati versi PBB Indonesia membatasi usia remaja antara 14 24 tahun (Wirawan, 2013).

Kita juga sepakat dengan batasan masa remaja sebagai periode peralihan, dimana seseorang beralih dari masa perkembangan sebelumnya, dari kanak-kanak ke dewasa. Peralihan ini pun pasti disertai goncangan, tidak saja karena secara fisik dan psikologis menyadari dirinya berbeda dengan orang lainnya, tetapi lebih dari itu perkembangan kognitif ala Piaget, perkembangan moral ala Kohlberg, pun perkembangan seksual ala Freud ikut berubah (ibid: 11).

Kesadaran diri remaja yang berbeda ini justeru menuntut kehadiran sebuah model komunikasi yang bertanggung jawab, artinya model komunikasi yang mampu menuntun remaja memaknai hidupnya dengan berbagai aktivitas positif, bukan sebaliknya menenggelam hidupnya dalam arus perubahan yang justeru mematikan enerji-enerji positif tersebut. Secara teoretis komunikasi interpersonal yang mendengarkan bisa dipakai orang tua untuk membantu remaja memantapkan diri berada dan menghadapi masa penuh risiko ini.

Dalam Handbook of Interpersonal Communication, Mark L. Knapp dan Daly John Agustine mendefinisikan komunikasi interpersonal sebagai kemampuan seseorang untuk membangun hubungan dengan orang lain lewat komunikasi tulisan pun komunikasi verbal (2002: 3). Definisi ini menuntut adanya media bahasa sebagai jembatan komunikasi. Komunikasi tatap muka dengan menggunakan bahasa yang saling menyapa dimungkinkan di sini.

Menurut Brook \& Heath (1993), komunikasi interpersonal adalah proses dengan apa informasi, makna, dan ungkapan perasaan dibagikan oleh seseorang. Informasi, makna, dan ungkapan perasaan bisa dilakukan melalui pesan-pesan verbal dan nonverbal. Para pakar yang dikutip Pastae (2016), seperti Peter Hartley, misalnya, mendefinisikan komunikasi interpersonal sebagai proses komunikasi yang berlangsung muka ke muka antara seorang individu dengan individu lain, yang bentuk dan isi komunikasinya merefleksikan karakter personal, aturan-aturan sosial, dan keterhubungan semua yang terlibat di dalamnya. Atau, Kory Floyd mendefinisikan komunikasi interpersonal sebagai bentuk komunikasi yang berlangsung di antara dua orang dalam konteks hubungan tertentu, terutama menyangkut kepentingan untuk menegosiasikan dan membuat batasan yang tegas bagaimana hubungan mereka diorientasikan. Atau, Denis Solomon dan Jennifer Theiss, mendefinisikan komunikasi interpersonal sebagai proses pemanfaatan simbol tertentu untuk mengungkapkan ide-ide 
supaya terjadi proses berbagi makna dan penciptaan ikatan pribadi di antara mereka yang terlibat.

Dalam studi ini mungkin lebih adil kalau kita menggunakan definisi Mark L. Knapp \& John Agustine karena dalam segala fungsinya komunikasi interpersonal menekankan tiga hal penting ini dalam penerapannya, yaitu mendengarkan (listening), menanggapi (talking), dan penyelesaian konflik (conflict resolution). Atau, dalam cara yang berbeda, namun memiliki implikasi pemahaman yang sama, Stewart L. Tubbs - Sylvia Moss menegaskan bahwa listening selalu menuntut kehadiran empat skema psikologis sekaligus dalam berhubungan dengan orang lain, yaitu: memperhatikan, mendengar, memahami, dan mengingat (Tubbs \& Moss, 2008).

Dalam kosa kata bahasa Indonesia kata listening dan hearing (mendengar) sering kali dipakai dalam cara yang sama, terutama dalam tata pergaulan sehari-hari, atau bisa juga dua kata ini dipakai secara bergantian untuk menunjuk pada situasi yang sama.

Hearing sebenarnya adalah sebuah proses netral, karena itu dia tidak selalu menuntut keterlibatan skema psikologis dalam berkomunikasi seperti dalam sebuah listening. Namun demikian, sebagai salah satu dari empat skema psikologis kualitas hearing menentukan efektivitas listening dalam komunikasi interpersonal. Karena, inti dari komunikasi interpersonal adalah berbagi makna di antara mereka yang terlibat dalam komunikasi (Ramaraju, 2012). Listening menjadi penting untuk memahami efektivitas komunikasi dengan remaja dalam keluarga sebagai ruang dia bermukim.

Dalam tradisi sosiopsikologis, Fitzpatrick (Littlejohn, 2013) mengasumsikan bahwa komunikasi dalam keluarga itu berpola berdasarkan skema tertentu yang sangat menentukan bagaimana anggotanya berkomunikasi. Skema tersebut memusatkan perhatian pada tiga bidang, yaitu: Seberapa dekat satu anggota keluarga dengan anggota yang lain; Bagaimana tingkat individualitas terbangun dalam keluarga; dan Bagaimana faktor eksternal memengaruhi keluarga tersebut.

Orientasi komunikasi dalam keluarga pun dapat terjalin dalam dua tipe, yaitu conversation orientation dan conformity orientation. Di satu pihak, tingginya conversation orientation membuat orang senang berbicara dan mengabaikan yang lain, sebaliknya rendahnya conversation orientation berakibat sebaliknya, orang akan diam. Di lain pihak, tingginya conformity orientation berdampak pada proses egalitarianisme, di mana setiap orang berjalan berdampingan, namun rendahnya conformity orientation berdampak pada tumbuhnya sikap individualistik pada individu (Littlehohn: 289).

Efektivitas komunikasi interpersonal dengan demikian sangat bergantung pada pemilihan tipe orientasi. Namun, tidak ada satu pun orientasi dianggap penting lalu yang lain diabaikan tetapi melakukan proses integrasi tipe orientasi untuk memaksimalkan manfaat yang diperoleh bagi anggota keluarga, termasuk remaja dalam menerapkan komunikasi interpersonal.

\section{METODE PENELITIAN}

Kajian sederhana ini berusaha melakukan review konseptual terhadap literatur-literatur yang tersedia. Dengan demikian metode yang dipakai dalam menjelaskan problema remaja ini adalah kajian pustaka yang bersifat deskriptif analitis.

\section{HASIL DAN PEMBAHASAN \\ 4.1. Masalah-masalah Remaja}

Seperti dikemukakan sebelumnya, sebagai sebuah periode peralihan masa remaja selalu ditandai oleh adanya transisi bermuatan konflik. Konflik bisa saja terjadi pada dirinya, pun kepada lingkungan sekitar hidupnya. Konflik, atau lebih tepatnya masalah pada remaja, secara psikologis berasal dari beberapa persoalan eksistensial yang mereka alami, yaitu: (1) masalah fisiologis; (2) masalah sosial; (3) masalah keluarga; (4) masalah akademis; dan (5) masalah yang berhubungan dengan nilai spiritualitas yang abstrak (Ahmadi \& Abutalebi, 2013).

Kegoncangan fisiologis dialami ketika seorang remaja menemukan dirinya dalam perbandingan yang tidak seimbang dengan apa yang dia alami, dan dia lihat dengan berbagai situasi di sekitarnya. Tidak mengherankan kalau konteks ini menghasilkan proses autoevaluasi dimana penilaian remaja berpusat 
pada dirinya yang sudah berubah. Mereka mulai mengevaluasinya secara normatif sebagai: baik, buruk, menarik, tidak menarik, cantik, tidak cantik, ganteng, tidak ganteng, dan lain-lain. Semua bentuk evaluasi diri ini lahir dari persoalan fisiologis yang dialaminya kini dan di sini.

Dalam menghadapi konflik fisiologis, seorang remaja bisa saja mengalami diorientasi secara sosial. Kehadiran orang lain, apalagi kalau kehadiran orang lain yang lebih menarik atau lebih baik darinya dilihatnya sebagai gangguan akan stabilitas keutuhan diri.

Dampaknya, kelompok sebaya dan menjadi anggota di dalam kelompok tersebut dialami sebagai tempat tumbuh paling pas, tidak saja untuk terbangunnya rasa aman, tetapi lebih dari itu kelompok sebaya diidentifikasi sebagai locus homogenisasi kebaikan, keindahan, dan kemenarikan. Kekuatan sebagai tumpuan untuk berkembang diidentifikasikan dalam kelompok. Maka, tidak mengherankan kalau para remaja mengalami kelompok sebayanya sebagai kekuatan dalam peristiwa apa pun dalam hidup mereka.

Perilaku tawuran remaja adalah ilustrasi paling mungkin untuk memperlihatkan bagaimana seorang remaja mengalami kekuatan penuh justeru ketika dia berada dalam kelompoknya. Perilaku yang timbul dari kesepakatan kelompok dipegangnya sebagai norma maka rasa bersalah akan muncul dengan sendirinya kalau perilakunya mengecewakan kelompok tersebut.

Fenomena sosial, seperti: narkoba, tawuran, mabuk-mabukan, dan seks bebas menjadi simptom kekuatan paling menakutkan ketika remaja melihat kelompoknya sebagai sumber norma. Para remaja berisiko lebih tinggi narkoba dan penguna aktif alkohol justeru dalam kelompok yang sengaja mereka bentuk (Carrol \& Sissi, 1997).

Dalam arti tertentu masalah para remaja, disadari atau tidak disadari sebenarnya sengaja didesain orang tua. Terlampau tingginya harapan orang tua tanpa memperhitungkan kemampuan remaja menampung besarnya harapan tersebut dalam situasi sosial yang berubah cepat bisa menimbulkan konflik tersendiri bagi remaja.
Harapan tinggi orangtua memang dapat dimaklumi karena mereka memiliki norma sendiri dalam memandang remaja. Perintah yang mewajibkan, di satu sisi, dan larangan yang ditanggapi sebagai yang membelenggu, di sisi yang lain, turut memicu pemberontakan remaja. Dalam hal-hal seperti ini, orangtua menemukan dirinya dalam kesulitan untuk memahami remaja, yang seolah-olah mereka menemukan jalan baru bagi ekspresi spirit pemberontakannya (Hunker \& Gray, 2000).

Perlu pula diingat bahwa para remaja bermasalah tidak saja ditandai oleh perilaku pemberontakannya terhadap berbagai aturan yang serba seragam dan dogmatis tetapi juga mengalami situasi misprestasi, terutama dalam bidang akademis. Lihat saja fenomena umum yang terjadi pada remaja, yaitu: menurunnya prestasi akademis mereka di sekolah. Simpton meredupnya prestasi akademis sebenarnya dapat terlihat dalam berbagai gejala, seperti: kemauan belajar mulai memudar; penurunan fokus dan konsentrasi pada cara belajar yang benar; rencana belajar yang tidak terencana; tanggung jawab diri yang rendah; dan yang paling mengkuatirkan adalah hilangnya rasa percaya diri pada remaja. Meski sebagai akibat, penurunan prestasi akademik ini sebenarnya dampak langsung dari pemberontakan remaja terhadap norma seperti digambarkan di atas.

Di atas semua masalah yang digambarkan di atas pencarian nilai dan proses menemukan nilai yang pas bagi kehidupan remaja menjadi masalah tersendiri. Kita sepakat bahwa proses mencari identitas diri adalah tanda khas konflik yang mewarnai hidup remaja. Spiritualitas keagamaan yang diajarkan di rumah dan sekolah tidak lagi memadai untuk menjadi panduan ke arah perkembangan positif. Makna hidup yang sedang dicari remaja mendapat jawabannya justeru dalam berbagai perintah dan larangan yang dihasilkan oleh keluarga, sekolah, bahkan agama. Kita pasti sepakat bahwa cara institusi spritual memberi perintah justeru menimbulkan tingkat resistensi yang tinggi dari remaja yang membutuhkan penyaluran ekspresi diri.

Persoalan ini menimbulkan masalah lain bahwa remaja mulai berani mempertanyakan urgensi dari nilai-nilai kehidupan sebagai norma, termasuk nilai 
agama. Norma agama tidak lebih nyaman dibandingkan dengan norma yang dibangun dengan menggunakan kerangka moral berbasis komunitas sebaya mereka. Ekspresi relijius keagamaan tidak lebih penting dari ekspresi kultis berbasis kepentingan dalam komunitas yang mereka bangun sendiri dalam kerangka norma yang dibangga-banggakan.

Semua masalah remaja yang digambarkan ini riil. Dalam forum ini masalah-masalah tersebut sengaja diangkat ke permukaan untuk menemukan cara yang cocok untuk mengatasinya. Begitu banyak masalah begitu banyak pula cara yang harus dimiliki orang tua, tidak untuk menyelesaikan tetapi untuk menjawabinya dengan penuh tanggung jawab. Saya berpikir bahwa orang tua harus merasa memiliki tanggung jawab menemukan cara yang cocok tersebut.

\subsection{Usaha dari Orang Tua}

Orang tua memerlukan panduan sebagai kerangka penguatan intervensi dalam menjawabi persoalan yang dialami dan dihadapi remaja kita. Perlu strategi khusus dan khas, tetapi perlu ditegaskan di sini bahwa sebagaimana beratnya masalah yang dialami remaja seberat itu pulalah tanggung jawab yang harus diemban orang tua menghadapi anak remajanya. Tidak semua masalah remaja bisa diatasi dengan cara yang sama. Masalah yang khas memerlukan penanganan yang khas pula.

Dari banyak studi tentang kajian remaja selalu diingatkan tentang peran sentral orang tua. Per definisi kita tahu bahwa orang tua adalah mereka yang secara moral harus dekat dengan anak mereka. Dekat, tidak saja dalam pengertian fisik, tetapi keterlibatan penuh secara emosional pada kehidupan remaja sehingga menciptakan rasa nyaman. Kedekatan emosional yang nyaman memungkinkan keterbukaan berkomunikasi. Komunikasi yang baik dan terbuka antara orangtua dan remaja memungkinkan terbangunnya perkembangan diri positif dan rasa percaya diri yang kuat. Perlu dipahami bahwa, meskipun, di satu sisi, masa remaja dianggap sebagai masa penuh tuntutan kebebasan, namun di pihak lain dalam masa ini remaja juga menuntut kedekatan relasi (close relationship) dengan orang tua mereka
(Golstein, Connie \& Elise van den Hoven: 2013).

$\begin{array}{llr}\text { Maka } & \text { orang tua harus merasa } \\ \text { bertanggung } & \text { jawab untuk memenuhi } \\ \text { kebutuhan } & \text { remaja memantapkan }\end{array}$
perkembangan diri yang positif dan bertanggung jawab dalam satu lingkungan sosial tertentu. Dari sisi spiritualitas keagamaan basis keimanan dan keyakinan harus diperkuat, karena hanya dengan cara itu seorang remaja merasa memiliki pegangan dasar untuk melangkah maju menemukan orientasi hidupnya yang positif. Keyakinan berbasis iman menjadikan remaja memahami hidupnya sebagai tugas yang wajib dijalankan, tidak saja untuk orang lain, tetapi yang lebih penting lagi untuk perkembangan jati dirinya yang sempurna bersama orang lain tersebut.

Dalam konteks ini kaum remaja seharusnya diberi kesadaran psikologis bahwa hidupnya tidak sendirian tetapi ada bersama orang lain. Orang lain, bisa orang tua di rumah, guru di sekolah, atau pun teman bermain, dengan caranya sendiri memberi peranan tertentu bagi perkembangan diri remaja, baik dari sisi emosional, pun sisi spiritual keagamaan. Para remaja memang harus dibantu untuk membentuk identitas dan kepribadian berdasarkan prinsip pengembangan proses pendidikan.

Banyak hal bisa dilakukan orang tua menghadapi remaja dengan segala problematikanya yang khas. Namun, harus ditegaskan bahwa pola pendampingan remaja seharusnya menyentuh dasar kebutuhan mereka. Satu masalah yang timbul sebenarnya sudah mencerminkan kebutuhan tertentu. Kebutuhan itulah yang mestinya disalurkan orang tua dengan cara yang sesuai dengan tingkat perkembangan mereka.

Sudah terbukti bahwa perspektif pendampingan yang berbasis orang tua akan sulit diterapkan, kalau tidak mau disebut gagal, karena para remaja memiliki perspektif sendiri sebagai standar untuk menentukan tentang apa yang baik secara normatif; apa yang mestinya dilakukan; dan apa yang mereka butuhkan dalam hidup.

Orang tua memiliki kewajiban luhur untuk membangun motivasi remaja sehingga mereka bisa melangkah maju menemukan diri dalam semangat untuk terus percaya pada 
kemampuan dirinya; mampu mengontrol dirinya menghadapi dunia yang serba baru dan menawarkan kemudahan instan; dan pada akhirnya dia mampu menghargai dirinya sebagaimana dia juga menghargai orang-orang lain di sekitar lingkup hidupnya.

Proses penanaman kepercayaan diri pada remaja penting dilakukan karena stres dan ketakutan adalah dua hal yang selalu menghantui hidup, apalagi kalau kita sedang menghadapkan mereka kepada pilihan-pilihan yang ambivalen. Mereka stres karena, di satu pihak, mereka tidak melihat satu pun nilai yang dihasilkan pranata keluarga dianggapnya memberi kebebasan, sementara di sisi yang lain, pada saat yang sama mereka merasa takut kalau pilihan kebebasan yang mereka ambil justeru melanggar tata nilai yang sudah ada dalam keluarga atau masyarakat pada umumnya.

Dalam hal ini, tidak ada pilihan yang lebih berharga selain, orang tua wajib meminimalisasi stres dan rasa takut tersebut dan memberi penegasan sekali lagi bahwa hidup anak remaja adalah hidup bersama orang lain (orang tua). Mereka, sekali lagi tidak hidup sendirian. Yakinkan mereka bahwa anda (kita, orang tua) ada untuk selalu menemani mereka dalam proses pembentukan identitas diri yang stabil.

Selain itu orang tua perlu sekali menyiapkan kondisi yang benar untuk berpartisipasi dalam wilayah aktivitas remaja, baik dalam keluarga, sekolah, maupun dalam lingkungan sosial. Strategi ini penting dilakukan, tidak saja untuk meminimalisasi rasa takut, stres, dan kesendirian (Ahmadi, Taghli Abutalebi, 2013: 363-364), tetapi juga menumbuhkan rasa kepercayaan diri remaja bahwa aktivitas mereka diapresiasi dan ditempatkan dalam perspektif yang sama dengan aktivitas orang tua.

Pilihan ini pun menjadi tidak mudah karena orang tua wajib mempelajari keterampilan dan teknik berkomunikasi yang khas dan tertentu. Komunikasi yang memberi ruang bagi terbangunnya interaksi positif sehingga kepercayaan diri remaja, tidak saja dibangkitkan, tetapi lebih dari itu harus terus dipertahankan untuk menyambut masa depan mereka secara bertanggung jawab.

Seperti dikatakan sebelumnya bahwa sebagaimana beratnya masalah yang dialami remaja maka seberat itu pulalah tanggung jawab yang harus dipikul orang tua, tidak berarti orang tua berpandangan bahwa masalah remaja sulit diatasi. Bagaimana mungkin orang tua bisa menanamkan rasa percaya diri kepada remaja kalau mereka sendiri tidak yakin bahwa masalah remaja bisa diatasi dengan cara yang memuaskan dan bertanggung jawab.

Kehadiran orang tua dalam masalah yang dihadapi remaja seharusnya memberi jaminan kepastian bahwa masalah tersebut bisa diatasi. Jaminan yang diberikan orang tua, tidak saja untuk menumbuhkan rasa kepercayaan diri, tetapi juga memacu kemandirian seorang remaja sehingga pada saatnya dia belajar menyelesaikan masalahnya sendiri.

\subsection{Model Komunikasi}

Hoppe \& Cunningham, yang dikutip Wilsher Dennis Rowen, dkk, mengatakan bahwa komunikasi adalah bagian penting dan vital dalam proses membangun sebuah relasi. Komunikasi adalah komponen dasar bagi orang tua dalam mendampingi dan memberi dukungan kepada anak remaja. Orang tua perlu membangun komunikasi dua arah sehingga mampu memahami apa sedang dipikirkan remaja. Mereka membutuhkan orang tua yang mendengarkan bukan memberi penghakiman. Komunikasi yang terbuka, empatik, dan memberi ruang untuk berbagi pengalaman pribadi memungkinkan dekatnya sebuah relasi itu dialami (Rowen, Wilsher Dennis, dkk., 2005).

Maka, dari sekian banyak model komunikasi yang ditawarkan kiranya penting menganjurkan model komunikasi yang mendengarkan (listening) ketika menghadapi remaja-remaja bermasalah. Meskipun kompleks dan harus dipelajari dengan tekun komunikasi dengan pola mendengarkan ini pada intinya meliputi beberapa hal penting, yaitu: kepedulian, mendengar, menafsir, mengevaluasi, dan tanggapan atas pesan untuk berbagi pengertian.

Ditarik kepada persoalan remaja maka cara-cara inilah semestinya dilakukan orang tua dalam keluarga. Keluarga ditandai oleh relasi yang dibangun secara mendalam melalui komunikasi interpersonal. Idealnya komunikasi keluarga menyiapkan lingkungan 
yang kondusif bagi remaja untuk mengembangkan otonomi dirinya (Disiye, 2015).

Dasar untuk membangun perilaku mendengarkan efektif tidak lain adalah kesediaan untuk belajar memahami orang lain. Dalam hal ini, memahami remaja. Mendengarkan adalah proses batin dimana seseorang harus sepenuh-penuhnya terlibat pada masalah-masalah yang sedang dihadapi. Untuk itu proses mendengarkan harus menyenangkan; mampu memilah apa yang perlu ditanggapi dan apa pula yang tidak mesti diberi tanggapan; mendengarkan juga harus kritis dalam arti menanggapi apa saja yang berhubungan dengan masalah sedang dihadapi; mendengarkan juga harus bersifat empatik (kita berada sebagai bagian dari pemecahan masalah); dan tentu mendengarkan yang penuh perhatian (Tubbs \& Moss, 2008).

Rice (1998), dalam artikelnya berjudul "Are You Listening" memberi beberapa penekanan ketika kita melakukan pola komunikasi mendengarkan. Proses komunikasi yang mendengarkan meliputi: (1) Mendengarkan secara aktif. Dalam hal ini keputusan untuk mendengarkan adalah sebuah komitmen yang membutuhkan keterlibatan pikiran, hati, dan emosi; (2) Mendengarkan dengan membaca berbagai isyarat verbal dan nonverbal. Makna, kerinduan, kebutuhan, dan keinginan bisa diekspresikan secara terang benderang melalui ungkapan kata-kata, tetapi banyak pula diantaranya diungkapkan melalui isyarat nonverbal atau yang tidak terucapkan. Sebuah makna dalam pesan nonverbal lebih banyak bersifat tersembunyi. Mendengarkan adalah cara menyingkapkan makna tersebut; (3) Mendengarkan untuk merefleksikan pandangan dan juga perasaan lawan bicara sehingga kita dapat menentukan pola yang sesuai kepada siapa dan dengan cara apa kita bisa melakukan intervensi tertentu; (4) Mendengarkan yang memungkinkan timbulnya kemampuan mengidentifikasikan dan mengatasi berbagai hambatan komunikasi dengan orang lain; (5) Mendengarkan untuk memahami proses dan alur komunikasi yang dibangun sehingga bisa dipahami ke mana arah yang mau ditujuh oleh sebuah komunikasi; (6) Mendengarkan untuk memudahkan kita memberikan feedback yang positif atas pesan yang diterima; (7)
Mendengarkan mengajukan pertanyaan; dan yang terpenting dari semuanya adalah; (8) mendengarkan dengan mengambil teknik yang berfokus kepada yang sedang dibicarakan atau dialami.

Sebagai bagian dari komunikasi interpersonal mendengarkan diasumsikan dapat memicu banyak keberhasilan seseorang, tidak saja berhubungan dengan karier profesional atau bakat menjadi pemimpin, tetapi juga sukses dalam hidup berkeluarga dan bermasyarakat. Atau, mendengarkan yang baik mampu memproduksi kepuasan dan suskes (Rice, 1998).

Sebagaimana dijelaskan sebelumnya peralihan dari satu masa ke masa perkembangan berikutnya selalu diikuti kebutuhan tertentu. Begitulah yang terjadi pada remaja kita. Apa yang mereka butuhkan? Bukan kemarahan, bukan penghakiman, bukan pula perilaku membandingkan anak dengan orang lain. Mereka butuh didengarkan.

Orang tua mestinya harus menyadari bahwa mendengarkan adalah cara untuk melawan kecenderungan egoisme diri. Hanya dengan mendengarkan orang tua mampu menyerap apa yang remaja harapkan. Hanya dengan mendengarkan masalah remaja dapat dimengerti. Dengan mendengarkan pilihan solutif bisa ditemukan.

Vanderlip (2006) membagi teknik mendengarkan kepada para orang tua lewat pola komunikasi nonverbal, antara lain: (1) Sadarilah tubuh anda adalah pesan yang kuat. Karena itu bahasa tubuh harus mampu memberi penguatan pada remaja anda; (2) Berkomunikasilah dengan cara memandang tenang pada matanya untuk menunjukkan bahwa anda peduli; (3) Selalu mengambil sikap tenang dan jangan pernah menghakimi perilakunya secara normatif berdasarkan ukuran kita; dan (4) Ekspresikan diri serilex mungkin dan berilah senyum yang tenang pada wajahnya.

Cara berkomunikasi seperti ini memberi ruang kepada remaja untuk dekat dan intim dengan orang tuanya. Dan, keberhasilan sebuah komunikasi sampai pada tahap intim hanya bisa diperoleh kalau mampu dibangun secara adekuat dalam suasana saling kepercayaan antara orang tua dengan remaja.

Mendengarkan pada tahap ini bisa diukur dari sensitivitas empati orang tua pada 
remaja, yaitu: kemampuan untuk memahami dan menerima remaja tanpa prasangka (Rice, 1998). Mendengarkan dengan empati memungkinkan meningkatnya kepercayaan sekaligus harga diri remaja di dalam lingkungan sosialnya.

Ruang keterbukaan untuk berpendapat mestinya dibuka. Para remaja tahu bahwa hanya anda (orang tua) yang mampu memahami mereka. Susie Vanderlip sekali lagi memberi rekomendasi bahwa ketika remaja anda berbicara maka anda hanya diberi kesempatan untuk melakukan tiga hal ini: mendengarkan, mendengarkan, dan mendengarkan. Berilah tanggapan sejauh membuat perasaannya nyaman dan merasa diterima.

Di sinilah efektivitas komunikasi terjadi ketika seperangkat kemampuan verbal, nonverbal, kemampuan mengelola stres, kapasitas mempercayai, memahami emosi menyatu dengan kemampuan mendengarkan kepada siapa kita sedang berkomunikasi. Secara emosional kemampuan ini memberikan kepada kita (dalam hal ini orang tua) kemungkinan untuk mengerti secara empatik masalah remaja dan memahami diri sebagai bagian dari pemecahan masalah mereka (JoAnn, 2012).

\section{SIMPULAN DAN SARAN}

Kehadiran remaja dengan segala problematika yang menyertainya adalah given, tidak ada satu orang pun, termasuk para orang tua bisa menolak kenyataan ini. Sebenarnya problematika yang dialami remaja dapat dilihat sebagai problematika kodrati, artinya masa/periode ini memang sebenarnya seperti itu adanya, bahkan para orang tua pun harus menyadari bahwa mereka pun pernah melewati periode penuh kegalauan ini dalam hidupnya.

Maka, pengalaman sebagai sejarah yang pernah dialami menuntut pemahaman total para orang tua bahwa problematika remaja secara intrinsik memuat begitu banyak kebutuhan yang mestinya dijawab orang tua secara bertanggung jawab. Masalah-masalah, pemberontakan, dan konflik yang dihadapi bahkan yang diciptakan remaja merupakan ekspresi dari beragam kebutuhan remaja yang tidak mampu dijawab secara tuntas oleh para tua.
Orang tua memang tidak pernah jauh secara fisik dengan para remaja namun secara psikologis mereka sengaja dijauhkan dari pemenuhan berbagai kebutuhan psikis mereka. Kecenderungan menyalahi dan menghakimi tidak lain dari cara orang tua mengalihkan perhatian untuk tidak memberi kepada remaja ruang ekspresi diri bagi haknya menyatakan kerinduan.

Remaja membutuhkan sahabat pendengar, tidak lain itu adalah orang tua. Sejauh mungkin agar para remaja dicegah supaya tidak terlanjur menjadikan sebaya mereka sebagai pendengar, karena tidak jarang, berbagai social disorder, bahkan berbagai penyimpangan sosial yang mereka lakukan secara koletif, mereka anggap sebagai kebaikan koletif pula. Hal ini berbahaya karena mereka cenderung permisif dengan nilai yang mereka bangun, tanpa fondasi normatif yang memadai sebagai pemberi isyarat dari otoritas sosial yang lebih tinggi, dalam hal ini orang tua, atau keluarga pada umumnya.

Bangun relasi interpersonal melalui komunikasi yang mendengarkan adalah cara terpenting untuk memahami lika liku kehidupan para remaja. Komunikasi mendengarkan yang empatetik adalah cara orang tua merasa menjadi bagian dalam permasalahan remaja karena sejarah yang sama pernah menggiring orang tua melewati periode yang mengagumkan sekaligus menakutkan ini.

Komunikasi yang mendengarkan berarti komunikasi yang terlibat, terutama dalam menjawabi berbagai kebutuhan psikologis remaja. Sekali lagi, segala bentuk pemberontakan remaja untuk menuntut kebebasan adalah ekspresi dari kebutuhan tertentu yang mestinya segera dijawab para orang tua, dan mendengarkan apa yang mereka harapkan adalah salah satunya.

\section{DAFTAR PUSTAKA}

Ahmadi, Taghi Abutalebi. (2013). "Stress and Anxiety in Adolescence" European Online Journal of Natural and Social Sciences: Departmen of Education, Farhangian University: Tehran 
Brooks, W. \& Heath R. (1993). Speech Communication, W.C. Brown. Dubugue, IA.

Califano, Joseph A. (2008), "Hands-On Parenting, How Parents Can Prevent Teen Drug Abuse", Journal Amarica. Technology Collection.

Carrol, Pamela Sissi. (1997). “Today's Teens, Their Problems, and Their Literature: Revisiting G. Robert Carlsen's Book and the Teenage Reader Thirty Years Later", English Journal.

Disiye, Margaret A \& Hezborn M.N. Kodero. (2015). "Influence of Parent-Adolescent Communication on Adolescent Peer Relation and Gender Implication" Journal of Art \& Humanities. JAH, Vol. 04.

Golstein, Connie \& Elise van den Hoven. (2013) "Facilitating Parent-Teenager Communication through Interactive Photo Cubes". Pers Ubiquit Comput. Eindhoven University of Technology.

Hunker, Paula Gray. (2000). Teens Behaving Badly. Insight on the News. Technology Collection.

Jo-Ann. 2012. "How to Become an Effective Communicator". Penton Media, Inc. Nov 26.

Knapp, Mark L. \& Daly John Agustine. (2002). Handbook of Interpersonal Communication, Cambridge University Press. New York.

Littlejohn, Stephen W \& Karen A. Foss. (2013). Teori Komunikasi Terj. Theories of Human Communication. Salemba Humanika. Jakarta.

Liuhua Ying, dkk. (2015). "Parental Monitoring, Parent-Adolescent Communication, and Adolescents' Trust in Their Parents in China", Plos One.
McCaffrey, Susan. (1998). "Teen-Adult Conflict: Working It Out", School Library Journal. Technology Collection.

Pastae, Veronica. (2016). "Interpersonal Communication In The Era of eCommunication", "Makalah Seminar" yang disampaikan pada The 12th International Scientific Conference elearning and Sofware for Education, di Bucharest, 21-22 April 2016.

Ramaraju, S. (2012). "Psychological Perspectives On Interpersonal Communication" dalam Jurnal of Arts, Science \& Commerce, Vol. - III, Issue 4.

Rice, Elizabeth J. (1998). "Are You Listening". Quality Progress. Technology Collection.

Rowen, Wilsherl Dennise, Shaw Perry. 2005. "Essensial Components of Mentoring Program for Pregnant and Parenting Teens" dalam American Journal of Health Studies. Indiana University. Bloomington.

Sarwono, Sarlito Wirawan. (2013). Psikologi Remaja. PT. RajaGrafindo Persada. Jakarta.

Tubbs, Stewart L, Silvia Moss. (2008). Human Communication (terj. Deddy Mulyana). Rosdakarya. Bandung.

Vanderlip, Susie. (2006). "Understanding the Physical Changes Your Patients are Going Through Can Help You Communicate Better with Them". Anthem Media Group. Los Angeles. 